\title{
Might Overcoming the Explanatory Gap Be Like Overcoming Vitalism?
}

It seems to be a commonly held belief or hope, though one that is often left at a primitive state of articulation, that the vitalism-mechanism controversy is a success story whose complete telling would include an account of an initial problem very much like the mindbody problem that is still with us today. The appeal of the analogy is clear: if it is genuine, the analogy bodes well for the prospects of a conceptually satisfying physicalist resolution to the mind-body problem.

By a "conceptually satisfying" resolution to the mind-body problem I mean a resolution that closes the famous "explanatory gap" (Levine 1983). It would be an account that explains how phenomenal qualities of conscious states-pains, itches, phenomenal sensations associated with seeing different colors, and so on-could be necessarily associated with physical processes like neural firings. Armed with this transparent necessary connection, the physicalist would be able to explain how it is that physical processes are identical to the relevant phenomenal qualities or at least how the physical processes are otherwise related to the phenomenal qualities in some intimate way that entirely accounts for the phenomenal qualities in physical terms. Such an explanation would leave room for no non-physical residue about the phenomenal quality to invite dualism.

The problem of the explanatory gap is that no such explanation is currently available, and it is very hard to see how one could ever be provided. Physical states about neuronal firings and electrochemical transmissions can surely be correlated with conscious states. No one denies that. To pick up a scientifically outdated example, one might discover that c-fiber firings are always associated 
with pain and that pain is always associated with c-fiber firings. But the association would still be in some important way gratuitous or arbitrary from our human perspective. Even if the connection is one that is characterized by the appropriate sort of necessity, our minds are not compelled by any conceptual necessity to make the connection; for all we can see into the nature of the connection, all of the very same physical phenomena could occur in the same patterns, perhaps as described by physical laws, without any of the typically associated phenomenal feelings of pain.

There is, on the other hand, a necessary connection that can be perceived by us between the non-violation of laws and the performance of what we can recognize to be the execution of certain other functions specified in higher level terms. Hence, the connection between phenomena of mind and physical laws or regularities is unfortunately different from the connection between phenomena of digestion and chemical laws. Suppose one understands laws governing how certain chemicals $\mathrm{x}$ will react in a solution of other chemicals y under background conditions $\underline{c}$ to produce $\mathrm{z}$, and suppose, naturally, that the laws are put entirely in physical or chemical terms; they do not mention digestion or food or organisms. One also recognizes digestion as the process of breaking down chemicals in foodstuffs so that they can be absorbed and used by the body. For example, when, in a human digestive tract, certain chemicals $\mathrm{x}$ are released from foodstuffs and converted into $\mathrm{z}$, which can be used to power cells, digestion has taken place. There is no conceptual room for us to maintain that the physical or chemical laws hold but deny that in a human digestive tract meeting conditions c, foodstuffs containing $\mathrm{x}$ in a solution of $\mathrm{y}$ will break apart and recombine in accordance with the laws to produce $\mathrm{z}-$ i.e., that digestion takes place. ${ }^{1}$

A genuine counterexample of a stomach meeting the right conditions but yielding the wrong reactions would show that there had to be something wrong with the putative chemical or physical laws. On the other hand, a counterexample to the association between pain and c-fiber firings need not upset our understanding of the laws or patterns observed in purely physical terms concerning the conditions under which neurons will fire, say. We might, for example, discover a war victim with a certain sort of brain damage that does not corrupt c-fibers but that does cause their firings to be associated with sensations of beer tasting rather than sensations of pain. We would have to revise the correlations we make

${ }^{1}$ This is not to deny the autonomy of the special sciences (see below, section II.2). Nor is it to make any assumptions about whether laws are in fact determinate, as is assumed in the example to illustrate conceptually transparent necessity. (Analogous epistemic claims would be made for laws that are not determinate.) Nor is it to deny that in practice it may be too hard for humans to collect the relevant information about chemicals in food and the environmental conditions in a digestive tract and then apply basic laws to determine outcomes in specific cases of, say, digestion. 
between physical states and mental ones, but not necessarily those that we make between physical states and other physical states.

This problem of explaining the relevant necessary relationship between phenomena of different conceptual categories appears, on its face, to be one that will not disappear without an entirely new conceptual scheme. But such a scheme resists articulation, naturally enough. So we are left with a problem, concerning which a number of writers have expressed varying degrees and forms of pessimism over our prospects for enlightenment (see also Chalmers 1996; McGinn 1999; Nagel 1979).

Auspiciously, past pessimistic worries of gainsayers seemed to be dissipated with the resolution of the apparently similar vitalism-mechanism controversy, which stands out to many as a paradigm success story illustrating how steady progress in chemistry and physics can banish conceptual blindness concerning any link between chemistry and physics and higher-level functions. Frequent allusions to this controversy in connection to the mind-body problem tend to be so cryptic and casual that it is often unclear just how the problems raised for comparison are supposed to be analogous, ${ }^{2}$ but it seems clear that scientific advancement in the study of mechanisms is supposed to have shined light on a problem that had earlier been the subject of pessimism concerning the conceptual possibility of any resolution. Because John Searle brings out the connection more clearly and explicitly than others of whom I am aware, I will appeal to him as a spokesperson in favor of the connection. In what follows, I will argue that there is no connection of the sort Searle and others would like to see. The vitalism-

${ }^{2}$ Thus, the following one-line comparison (albeit from a nine page review: de Sousa 2000), pregnant with hopeful connotation, is typical: "The task of 'naturalizing' the mind is just part of the revolution that has banished vitalism from biology, bringing the mind, like life, under the aegis of science." Chalmers (1996 pp. 108-9, 370-8) cites others who raise vitalism in connection with mind. Chalmers's reaction to the connection is similar to my reaction here, but our focus is not quite the same. Much of Chalmers's focus seems to be on whether his position that there is conscious experience is on stronger footing than vitalists' position that there are vital spirits; I, on the other hand, take conscious experience for granted in the way that vitalists took life for granted. I take conscious experience for granted (as does, for example, Searle, the principal opponent I cite below), in order to address the further issue of whether the collapse of vitalism shows that and how a greater understanding of mechanism can dissolve a mental block as to just how something like conscious experience (purportedly analogous to life, for vitalists) could ever be explained by physics and chemistry. So one possible physicalist response to the pessimism expressed here might be to refuse to recognize conscious experience at all. I find this response even less palatable than a decision that someone might make, in the face of trouble, not to recognize the phenomenon of life; but I will not discuss that here. Although our focus is not quite the same and although I came upon conclusions before seeing Chalmers's words about vitalism, there is much overlap between our conclusions and much of what Chalmers says seems to me to be corroborated by what I say here. 
mechanism controversy is no grounds for optimism about overcoming the explanatory gap. I do not know of any other more hopeful precedent or of any proposals for another more hopeful precedent. ${ }^{3}$

\section{An Articulation of the Analogy: Searle}

"How could we get a science of consciousness that would show why and how neuron firings cause feelings?" (Searle 1996). According to pessimists, "it would take a major scientific revolution to get us a theory of how and why neuron firings could give rise to subjective feelings of awareness" (1996). Such a revolution may or may not dawn, may or may not even be possible for beings with our cognitive capacities. But matters are not so grim, says Searle. "We've been in this situation before in the history of science" (1996). ${ }^{4}$ We emerged with a kind of scientific enlightenment that did not seem possible in advance. We were in this situation before when we were overwhelmed by the mystery of how life - rather than consciousness - could arise from matter. At that time,

the question was, could you explain life in chemical terms? How could you give an explanation of life just in these mechanical terms? And a lot of people thought you can't do it. You've got to postulate a kind of life spirit in order to explain how matter can be alive. You've got to postulate an elan vital (1996).

Fortunately, says Searle, more knowledge of biochemical mechanisms, knowledge gradually accumulated over lime, just dispelled the mystery, so that

now we can't even recover those issues. Now it just seems obvious to us that we have a biochemical account. And that is not because the mechanists, as they were called, won the battle and the vitalists lost - that's what happened - but more deeply, because we got a much richer theory of the mechanisms (1996).

Searle offers the analogy in a variety of publications. Here is a substantial quote from Minds. Brains and Science: ${ }^{5}$

${ }^{3}$ Searle does, in some places where he discusses vitalism, offer further support with a manifestly weaker, accessory analogy from physics that I will not discuss here.

${ }^{4}$ The underline here should be credited to me. A word of caution: the quotes from (1996) are transcribed from an oral lecture that is published in audio-format, and while I have tried to be faithful to the sense of the original in transcribing, Searle did not do his own underlining or italicizing on paper.

${ }^{5}$ Searle might be interpreted as supposing, when he offers this earlier passage, that even with the present state of science, the mystery should be seen as a kind of confusion in the light of vitalism's failure. His later words preclude this interpretation. For more discussion of the problem, see Searle (1992, pp. 1OOff.). 
I think that by pursuing an analogy with an earlier problem in the history of science we can dispel this sense of puzzlement. For a long time many biologists and philosophers thought it was impossible, in principle, to account for the existence of life on purely biological grounds. They thought that in addition to the biological processes some other element must be necessary, some elan vital must be postulated in order to lend life to what was otherwise dead and inert matter. It is hard today to realize how intense the dispute was between vitalism and mechanism even a generation ago, but today these issues are no longer taken seriously.... Once we understand how the features that are characteristic of living beings have a biological explanation, it no longer seems mysterious to us that matter should be alive (1984, p. 23). ${ }^{6}$

Searle proceeds optimistically:

I think that exactly similar considerations should apply to our discussions of consciousness. It should seem no more mysterious, in principle, that this hunk of matter, this grey and white oatmeal-textured substance of the brain, should be conscious than it seems mysterious that this other hunk of matter ... should be alive. The way, in short, to dispel the mystery is to understand the processes $(1984$, p. 23$)$.

I think that a closer investigation of the controversy between vitalists and mechanists shows that this analogy fails. It therefore remains very hard to see how more information about mechanisms could illuminate the mysterious connection between mind and body in the way Searle claims that more information about mechanisms will do.

\section{A False Analogy}

The darkness enshrouding the issue of how life arises from matter was of several varieties. Some of these varieties are simply not analogous to the darkness that Searle concedes attends the mind-body connection today. Other varieties of former darkness attending vitalism are analogous to the darkness that Searle concedes attends the mindbody connection today-but these varieties of darkness were never illuminated by more information about mechanism.

Let me elaborate. Earlier speakers used the term 'vitalism' to cover a confused nest of views that tended not to be distinguished from one another. As C. D.

\footnotetext{
${ }^{6}$ Notice that in this statement of the problem, the mystery is how to explain life in biological terms. This, of course, mischaracterizes the issue between vitalists and mechanists, because vitalists thought that they could explain life in biological terms - they just thought that such terms had to be vitalistic.
} 
Broad says before the end of the dispute, "both names cover a multitude of theories which the protagonists have never clearly distinguished and put clearly before themselves" (Broad 1925, p. 44; see also McDougall 1938, p. 75). Some theories on the vitalists' side have been or at least could in principle be corrected by more information about mechanism, but it is not easy to see how the connection between mind and body could be analogously illuminated. Other theories on the vitalists' side have not been corrected by more information about mechanism and it is hard to see how they ever could be.

\section{II.l. What Greater Knowledge About Mechanisms Could Resolve}

As I have indicated, vitalism amounts to more of a cluster or family of related doctrines than a single, well-defined position. Which members of the cluster are important varies with the time period under discussion? Some of the theses are as follows:

i. Only living tissues can produce organic chemicals.

Related to (i) are the theses:

ii. Only a vitalistic factor at work in living tissues can regulate development, and, more broadly,

iii. Living tissues are maintained by forces that do not occur outside of living bodies.

Let me begin with (i): the thesis that only living tissues can produce organic chemicals. A couple of centuries ago, most scientists thought that only a living tissue could produce organic chemicals. This vitalistic thesis was gradually undermined by successive experiments.

Our question is, How much comfort should the collapse of vitalistic thesis (i) provide for someone hoping that a greater understanding of mechanisms giving rise to consciousness will illuminate how mental phenomena are necessitated by physical ones? And the answer would seem to be: not much comfort. Vitalistic thesis (i) was always obviously open to empirical refutation and hence to an empirical resolution.

Granted, this vitalistic thesis was not easily refuted, and there was certainly trouble in seeing through the details of what might constitute an empirical refutation. But as much can be said of any empirical matter. Let me describe very briefly progress toward convincing the scientific community that thesis (i) is bankrupt and troubles attending that progress. I hope that this description reveals that the slow process of enlightenment was not one that could gradually emerge from similar experiments concerning the relation of mind and body. 
One of the most important discoveries undermining vitalistic thesis (i) was Friedrich Wohler's artificial synthesis of urea. Urea seemed to be organic, seemed to be synthesized by living bodies. Yet it can be synthesized using just ordinary chemicals, such as carbon, as we now see. A major historian of chemistry and a contemporary of Wohler, Hermann Kopp, remarks on the power of the discovery:

Of special importance for organic chemistry was [Wohler's] discovery (1828) of the artificial production of urea. This was the first example that an organic substance could be produced through chemical means alone from inorganic materials; this discovery destroyed the till-then accepted distinction between the organic and inorganic bodies, that, namely, the first only originate under the influence of vegetable or animal vitality, whereas only the latter could be produced through artifice (Kopp, H. 1843, p 442, quoted from Cohen and Cohen 1996, p. 884).

Although a number of textbooks today follow Kopp in listing Wohler as the man who laid this vitalistic thesis, or even the entire vitalism-mechanism controversy, to rest (see, for copious examples, Cohen and Cohen 1996), this vitalistic thesis far from disappeared upon Wohler's announcement of his results.

(Much less did the entire vitalism-mechanism controversy disappear.) The great Swedish chemist Jons Jakob Berzelius concluded that even if Wohler had artificially created urea, this did not refute vitalism, since urea must not be a fullblooded organic compound (Teich and Needham 1992, p. 452). There were further hitches. For example, Wohler obtained urea by heating ammonia with cyanate, the latter of which was generally considered an inorganic carbon compound. But Wohler had obtained the cyanate from the horn of an animal, which is clearly organic. Hence, the question remained: could it not be that products of living things, at least, are needed for urea's synthesis? If so, perhaps life is ultimately needed to produce organic compounds. This worried some in Wohler's day (Newmark 1993, p. 48).

Eventually these kinds of reservations took on less importance. Wohler's was the first in a line of experiments to show that organic chemicals can be synthetically reproduced. Some of the loose ends from Wohler's experiment were tied when, in 1845, H. Kolbe synthesized acetic acid from raw materials that were purely inorganic. This and other experiments made it clear that organic chemicals could be so created.

Still, the retreat from vitalism was a process of gradual dawning. When it was granted that organic chemicals could be so created, vitalism was still not finished. Rather, vitalists made less sweeping claims about what could or could not be created artificially. In the eighteenth century the relevant vitalistic position maintained that every phenomenon of life and of the mind is an activity of the life spirit, and incapable of scientific description. Opponents restricted themselves to saying that a large portion of such phenomena can be described in accordance 
with the laws of chemistry and physics. In the following century, to be counted an opponent of vitalism you had to hold that every phenomenon of life and mind can be reduced to laws of physics and chemistry (Emmeche, Kpppe and Stjernfelt 1997, pp. 8688). So experiments caused vitalists to limit their claims to fewer phenomena, and to gradually allow that many biological phenomena could be explained scientifically. Opponents of vitalism, encouraged by experimental results, gradually became more aggressive. In this way the vitalism-mechanism controversy evolved to accommodate the findings of the latest experiments.

Louis Pasteur would be defending vitalism decades after Wohler's experiment. Pasteur could argue that there is need for living organisms in fermentation even if he had to acknowledge that urea can be artificially created. Eventually, Pasteur's claim was shown wrong in its own turn. While Pasteur was right that living organisms were involved in the fermentation he studied, he was not right that such fermentation could not happen in the absence of a living ferment. Hence, his own argument fell by the wayside in much the same way that the earlier argument defeated by Wohler did.

Today, of course, scientists unanimously reject the vitalistic position that it takes life to produce organic chemicals. ${ }^{7}$ Many modern drugs are synthetically manufactured organic compounds. It is safe to say that the vitalistic thesis that organic chemicals can be created only in living tissue is just a mistake. Enough examples of the production, in a laboratory, of organic chemicals have convinced us of this. But although controversy about thesis (i) has been resolved by a gradual accumulation of knowledge about chemistry, this resolution does not reveal how something similar could happen for the mind-body problem. As I have indicated, vitalistic thesis (i) was always clearly open to a decisive empirical resolution. Vitalists were skeptical of whether existing mechanical laws would allow for the creation of certain chemicals in a lab: greater knowledge of mechanisms could clearly settle that. The question was not how any possible mechanical laws could ever be seen to allow for the creation of these chemicals. For that reason the resolution of (i) in favor of mechanists ought not to inspire optimism that the

\footnotetext{
${ }^{7}$ To say that the vitalistic position that it takes life to produce organic chemicals does not enjoy favor among scientists is not to say it does not enjoy favor among the lay population. Fessenden and Fessenden (1994, pp. 1-2) point out that vitalism has many adherents in the general public. Many people believe that vitamins and other organic compounds are better for the health if they have been produced by a living being than if they have been synthesized by scientists in a laboratory. Living tissue is supposed to have a power to manufacture organic chemicals that no laboratory worker can duplicate. That is why some people buy "natural" vitamins in a drugstore, in place of the cheaper artificially reproduced variety. Despite this extra money spent on natural vitamins, however, vitamin $\mathrm{C}$ is vitamin $\mathrm{C}$, whether created on an orange tree or in a laboratory. An orange offers nutrients other than vitamin $\mathrm{C}$, but so far as that nutrient goes, the vitamin $\mathrm{C}$ in an orange is not any different from that which scientists synthesize.
} 
conceptual issue concerning how mental phenomena could arise from physical ones will be resolved in parallel fashion.

Recall, too, that the question at issue is whether the mind-body problem can be resolved or dissolved with a more intimate understanding of biochemical mechanisms. Here, too, there is a disanalogy between the hoped-for resolution to the mind-body connection and the putting to rest of vitalistic thesis (i): an understanding of biological mechanisms themselves has little directly to do with the refutation of thesis (i), since that thesis was always open to empirical refutation by the production of organic chemicals independently of how well or poorly the attending mechanisms behind this production might have been understood. This point is reinforced by a look at thesis (ii).

Thesis (ii) is the thesis that only a vitalistic factor at work in living tissues can regulate development. This was one of the major claims of Hans Driesch, the leading vitalist of the twentieth century (Driesch 1908; 1914; see, e.g., Medawar and Medawar 1983; Bechtel and Richardson 1998). A few years prior to Driesch's key work on the topic, Wilhelm Roux had described an experiment that he thought showed that development is determined by hereditary determinants distributed piece by piece throughout a fertilized egg. As the cell divides, Roux hypothesized, the descendant cells develop into the parts that they are genetically determined to become on account of their initial genetic differences, which differences continue to be present in the better-defined parts of an organism as it grows. So development is determined mechanically by hereditary material that is divided among the parts of an expanding, multicellular organism. Roux supported his hypothesis with experiments with fertilized frog eggs. As a fertilized frog egg divided, Roux killed one of the resulting blastomeres. When the remaining blastomere continued to develop, it developed into just half of an embryo. This, to his mind, suggested that development is mechanical.

Driesch followed up Roux's experiment in 1891 with a similar experiment involving sea urchins. After the urchin eggs had separated into two cells, Driesch separated them. Each cell developed into an entire organism. Driesch concluded that a vitalistic factor is at work.

Driesch's vitalism denies that any mechanistic account of development will suffice to explain the biological facts. Driesch did not conclude that physical and chemical mechanisms play no role in development, but he concluded that development is only partially determined by the laws of physics and chemistry.

Driesch's vitalism has been rejected. But has a greater understanding of mechanism dissipated it? That seems doubtful. With or without an account of the mechanisms, few have been willing to follow Driesch. Tellingly, Medawar and Medawar reject vitalism but concede, even fairly recently, 'Reading Driesch's lectures does, however, remind us how much there is still to explain and how far 
we still are from a full theoretical understanding of development" (Medawar and Medawar 1983, p. 277).

Granted, Driesch's vitalism could indeed be thoroughly defeated by greater understanding of the mechanisms responsible for development. Such an understanding would demonstrate that the mechanisms exist and perform the required work. But again, as I will show, there is no parallel to the mind-body problem here. Similar words apply to other forms of vitalism that precede Driesch and that have been more or less dispelled with a greater understanding of mechanism. This moves us to thesis (iii): that living tissues are maintained by forces that do not occur outside of living bodies.

Thesis (iii) is a broader form of (ii), and is maintained in other forms than Driesch's form by, for example, the French anatomist Xavier Bichat (1771-1802) and the great German chemist Justus Liebig (1803-73). ${ }^{8}$ For Bichat, biological organisms manifest forces of nature like those more general forces that Newton discovered. For Liebig, physical and chemical forces account for processes like digestion, but these processes also require the regulatory assistance of a vital force.

These forms of vitalism have been rejected, as the forces claimed by the men have not been found. But in these cases it is very clear that the question illuminated by greater understanding of mechanisms is not the conceptual one of how any physical mechanisms or forces could ever give rise to higher and conceptually distinct properties. On the contrary, the question illuminated is simply an empirical question about what physical mechanisms or forces there are actually operating in an organism. And it is hardly surprising that a greater understanding of mechanisms should illuminate that question. No one would ever have doubted that such illumination could be provided by this sort of information.

It may be clearer that the question illuminated is simply a question about what physical mechanisms or forces there are in an organism when one recognizes that for Bichat and Liebig, the vital forces arise because of the organization of matter and they are simply forces like other forces, on a par with, say, gravity: there is no immaterial principle or spirit. While Driesch differs in that he appeals to an immaterial entelechy, his vitalism could similarly be dispelled by a greater knowledge of mechanisms: because on Driesch's account certain mechanisms are nonexistent, the discovery of such mechanisms would refute him. But here again, the question illuminated would be about what mechanisms there are at work in producing certain biological activities. The question illuminated is not about how any mechanical laws could ever direct development, but rather whether

\footnotetext{
${ }^{8}$ Both are discussed helpfully in Bechtel and Richardson (1998, p. 640). Bynum (1981) discusses Bichat and helpfully distinguishes his "vital materialism" from other forms of materialism. See also LaPorte (2004) on Liebig.
} 
mechanical laws actually do this work: Is this a Roux-like world or not? This is not the sort of question at issue with respect to the mind-body issue, and the discovery of more mechanisms can not be expected to shed similar light on the respective questions.

\section{II.2. What Greater Knowledge About Mechanisms Could Not Resolve}

Three more vitalistic theses are the following:

iv. All forms of sensibility, mind, consciousness, or in today's vocabulary "qualia" are the properties of an immaterial life spirit.

v. Free agency is a property of an immaterial life spirit.

vi. Biology cannot be reduced to chemistry and, ultimately, to physics.

vii. Life is an emergent property.

Start with (iv) and (v). That there is mind, including sensation, irritation, and other forms of consciousness, seemed to vitalists right to the end of the debate to vindicate their position: it is one of Wheeler's principal arguments for vitalism (Wheeler 1939, 250-251). Vitalists embracing (iv) simply thought that there is no satisfactory materialist answer to the question "How does consciousness arise?" But surely no further knowledge of mechanisms illuminated this question. If further knowledge of mechanisms had illuminated this question, then Searle would certainly have a strong purchase for claiming precedent - indeed, Searle would have understated the purchase that the earlier case provides - when he says more knowledge of mechanisms can illuminate why and how neuron firings cause feelings. He would have understated the purchase that the earlier case of vitalism provides because it would be better to say, rather than that there is precedent for the illumination of a question like his, that his own very question has already been illuminated. This difficulty for materialism or mechanism that is raised by vitalists just is the mind-body difficulty that Searle is trying to address. It's not an independent though parallel question in the realm of biology that has received a satisfactory answer. Vitalistic dualism may not appeal, but no understanding of mechanism has closed the explanatory gap that has turned adherents away from alternatives.

Closely related to the above vitalistic argument is the argument that free agency requires vitalism. Here again, Wheeler emphasizes the role of "volition and free-will" in the vindication of vitalism $(1939$, p. 254). In emphasizing the role of freedom, Wheeler follows Driesch $(1908 ; 1914)$, for whom freedom is one of the main arguments for the existence of a special vital entelechy (see also Beckner 1967 pp. 255-6). But again, free agency or apparently free agency is 
the sort of subject that one still hopes to see illuminated by mechanism - it is not the sort of subject that serves as a paradigm of clarity for emulation in the philosophy of mind.

It would be inaccurate to say that greater understanding of mechanisms has clarified earlier doubts about how material could give rise to the relevant phenomena discussed in (iv) and (v), thus eliminating vitalism. And, in fact, (iv) and (v) still enjoy some adherents. Discussion of the relevant issues is ignored by biologists but it continues in philosophy departments, where the adherents of some version or other of theses (iv) and (v) are called "substance dualists."

Theses (vi) and (vii) enjoy considerably more support, and broader support, in academic circles: these are still live issues discussed by both philosophers and biologists. For that reason, even to say that "vitalism" has collapsed is misleading: it is inaccurate to say that what speakers have all along called 'vitalism' has collapsed. I repeat, 'vitalism' never signified a clear, monolithic doctrine: it is rather a word that came to be associated with an untidy collection of more or less related theses, different combinations of which were adopted by different self-proclaimed "vitalists." Only some of the positions have been refuted or discarded. The word 'vitalism' has undergone a change in use since the controversy, so that that the word has become linked just to those refuted or discarded theses (LaPorte 2004).

As for whether biology can be reduced to chemistry and, ultimately, to physics, this will of course depend on what kind of reduction is in question. Different theorists propose different varieties of reduction. Consider Mayr's (1982, pp. 60-63) constitutive reduction. An affirmation of constitutive reduction in biology would amount to the claim that organisms are entirely composed of materials found in the inorganic world and recognized by chemistry. Some vitalists rejected constitutive reduction, embracing something like substance dualism. I have already discussed reasons offered in support of this position. But other vitalists accepted the possibility of constitutive reduction. I have already indicated that Bichat and Liebig would have.

Resistance to forms of reductionism other than constitutive reductionism could distinguish a vitalist. A number of nineteenth century thinkers defended "vitalism" precisely on the grounds that biology is not just applied physics and chemistry (see, on this point, Gregory 1977, p. 166), while mechanists attacked vitalism on the grounds that physiology would dissolve into physics and chemistry (see, e.g., Coleman 1977, p. 151). On this score, consider the great experimentalist and "vitalist" Claude Bernard. Bernard repudiated cruder versions of vitalism, but he also objected to "chemists and physicists who ... try to absorb physiology and reduce it to simple physico-chemical phenomena." He settled with a position he would call "physical vitalism," which recognizes that "biology has its owr. problem and its definite point of view" but that also recognizes physico-chemical 
determinism. ${ }^{9}$ Such a position resembles closely that of any number of philosophers and biologists today. The attractiveness of this position has certainly not dissolved in light of mechanisms discovered since the time of Bernard.

One might object that genetics has been reduced to chemistry now that DNA's structure is known, and that this illustrates how biological laws can be shown to be special cases of chemical or physical laws. But many are skeptical. One skeptical voice announces that in the field of genetics

biologists pretend to be chemical reductionists making DNA the ultimate cause of the organism - but all the time doing this by using higher level concepts like "information", "code", not to talk about "messenger-RNA"... It is perfectly possible to imagine a genetics deprived of any expressions foreign to chemistry, but any explanation of a recognized higher-level phenomenon must start with the higher- level phenomena in order to identify what to investigate, thereby using some identification of the process or object. A purely chemical genetics would be a branch of chemistry and would hardly be recognizable as genetics. This very identification can never be totally discarded in a lower-level explanation, because in the ultimate through-and-through lower-level explanation one might never know which higher- level phenomenon it was an explanation of. The reductionist idea to create a sort of dictionary, in which every higherlevel phenomenon can be translated to its micro-level constituents in itself proves that a conception of the higher level as merely reducible ... is never possible: one always has to use a description of the higher level to identify what is going on (Emmeche, Kpppe and Stjernfelt 1997, pp. 103-104).

Mayr agrees.

As gratifying as it is to be able to supplement the classical genetic theory by a chemical analysis, this does not in the least reduce genetics to chemistry. The essential concepts of genetics, like gene, genotype, mutation, diploidy, heterozygosity, segregation, recombination, and so on, are not chemical concepts at all and one would look for them in vain in a textbook on chemistry (Mayr 1982, p. 62).

If these skeptics are right, then even in the promising case of genetics we do not have a reduction of key terms in biology to chemical concepts, and this is to say nothing of terms like 'species', 'territory', 'hibernation', 'predation', 'courtship', and so on. Greater knowledge of mechanism has not resolved this matter.

Thesis (vii), also embraced by vitalists, or self-proclaimed "vitalists" (LaPorte

\section{4; Emmeche, Køppe and Stjernfelt 1997, p. 86), similarly enjoys contemporary}

9 These quotes are from Bernard (1957, p. 95). Bernard's claim to be a "physical vitalist" is discussed in, e.g., Olmsted and Olmsted (1952, p. 214), and Goodfield (1960. p. 162). 
defenders. More cautiously, many contemporaries acknowledge with earlier "vitalists" that life is an emergent property of some sort or other: emergence, like vitalism and reductionism, comes in a range of variously related kinds. Roughly, the emergent properties of a whole arise out of more fundamental properties of parts or more basic entities, but the emergent properties are in some way novel or irreducible to more fundamental properties.

That life is an emergent property of some sort or other is not an illusion that greater knowledge of mechanism has dispelled. Nor is it easy to see how greater knowledge of mechanism might dispel it.

Granted, there would seem to be confusion in some past emergentists' discussion of whether life-and not only life but other properties as well, like the properties of chemical substances - could be predicted or seen given only lower level laws (see, e.g., O'Connor and Wong 2002). Emergentism has a long history and, as in any philosophical tradition, one expects to see in it plenty of discord, confusion, and incoherence. Perhaps the history of emergentism. as opposed to vitalism, would be a promising place to look for confirmation of a hunch or hope that the mind-body connection now presents a problem similar to one from the past that has been resolved by gradually accumulated knowledge about mechanisms. I do not know of a promising candidate for a parallel to the mind-body problem in the history of emergentism but an examination of that tradition would require an essay of its own.

In any case, any real story behind conceptual progress in the past on problems faced by emergentists that might parallel the mind-body problem would presumably be a story about the idiosyncrasies of particular philosophers and their technical mistakes. It will not resemble the hopeful story of a vast fog that once covered the minds of large sectors of a scientific community and that concealed the possibility of an epistemically necessary connection between life and chemistry before being dissipated by the gradually dawning light of daily scientific grinding. It seems safe to conclude that it is an exaggeration at best to say, "We've been in this situation before in the history of science" and left our puzzlement behind.

\section{References}

Bechtel, William and Richardson, Robert. 1998. "Vitalism." In Routledge Encyclopedia of Philosophy, vol. 9, ed. Edward Craig, pp. 639-42. London: Routledge.

Beckner, Morton. 1967. "Vitalism.” In The Encyclopedia of Philosophy, vol. 8, ed. Paul Edwards, pp. 253-6. New York: Macmillan.

Bernard, Claude. 1957. An Introduction to the Study of Experimental Medicine. Translatec into English by Copley Green, with an Introduction by Lawrence J. Henderson and 
a Foreword by I. Bernard Cohen. New York: Dover. Originally published as Introduction a l'etude de la Medecine experimentale. Paris: J.B. Bailliere, 1865. Broad, C. D. 1925. The Mind and Its Place in Nature. New York: Humanities Press. Bynum, W. F. 1981. "Vitalism.” In Dictionary of the History of Science, ed. W. F. Bynum,

E. Browne and Roy Porter, pp. 439-40. Princeton: Princeton University Press.

Chalmers, David. 1996. The Conscious Mind. New York: Oxford University Press. Cohen, Paul S. and Cohen, Stephen M. 1996. "Wohler's Synthesis of Urea: How Do the

Textbooks Report It?" lournal of Chemical Education 73: 883-6.

Coleman, William. 1977. Biology in the Nineteenth Century: Problems of Form. Function. and Transformation. Cambridge: Cambridge University Press, de Sousa, Ronald. 2000. Review of Joelle Proust, Comment l'esprit vient aux betes :

Essai sur la representation. Dialectica 54: 320-328.

Driesch, Hans. 1908. The Science and Philosophy of the Organism. London: A. and C. Black.

Driesch, Hans. 1914. The History and Theory of Vitalism. London: Macmillan. Emmeche,

Claus, Kpppe, Simo and Stjemfelt, Frederik. 1997. "Explaining Emergence: Towards an Ontology of Levels." Journal for General Philosophy of Science 28: 83-119.

Fessenden, R and Fessenden, J. 1994. Organic Chemistry. 5th edition. Pacific Grove, CA: Brooks/Cole.

Goodfield, G. J. 1960. The Growth of Scientific Physiology. London: Hutchinson. Gregory, Frederick. 1977. Scientific Materialism in Nineteenth Century Germany.

Dordrecht: D. Reidel.

Kopp, Hermann. 1843-1847. Geschichte der Chemie, Vol. 1, Braunschweig: Druck und Verlag von Freidrich Bieweg und Sohn.

LaPorte, Joseph. 2004. Natural Kinds and Conceptual Change. Cambridge: Cambridge University Press.

Levine, Joseph. 1983. „Materialism and Qualia : The Explanatory Gap.” Pacific Philosophical Quarterly 64: 354-361.

Mayr, Ernst. 1982. The Growth of Biological Thought. Cambridge, MA: Harvard University Press.

McDougall, William. 1938. The Riddle of Life. London: Methuen.

McGinn, Colin. 1999. The Mysterious Flame: Conscious Minds in a Material World. New York: Basic Books.

Medawar, P.B. and Medawar, J.S. 1983. Aristotle to Zoos: A Philosophical Dictionary of Biology. Cambridge, MA: Harvard University Press.

Nagel, Thomas. 1979. Mortal Questions. Cambridge: Cambridge University Press.

Newmark, Ann. 1993. Chemistry, London: Dorling Kindersley.

O'Connor, Timothy and Wong, Hong Yu, „Emergent Properties”, The Stanford Encyclopedia of Philosophy (Winter 2002 Edition). Edward N. Zalta (ed.), URL = <http://plato.stanford.edu/archives/win2002/entries/properties-emergent/>.

Olmsted, J. M. D. and Olmsted, E. Harris. 1952. Claude Bernard and the Experimental Method in Medicine. New York: Henry Schuman.

Searle, John. 1984. Minds, Brains and Science. Cambridge, MA: Harvard University Press. 
Searle, John. 1992. The Rediscovery of the Mind. Cambridge, MA: MIT Press.

Searle, John. 1996. "How to Study Consciousness Scientifically." Lecture 9 of his audio recording The Philosophy of Mind. Springfield, VA: The Teaching Company.

Teich, Mikulaś and Needham, Dorothy. 1992. A Documentary History of Biochemistry, 1770-1940. Leicester: Leicester University Press.

Wheeler, L. R. 1939. Vitalism: Its History and Validity. London: Witherby. 